\title{
Semiquantified Noncalcified Coronary Plaque in Systemic Lupus Erythematosus
}

\author{
ADNAN N. KIANI, JENS VOGEL-CLAUSSEN, ARMIN ARBAB-ZADEH, LAURENCE S. MAGDER, JOAO LIMA, \\ and MICHELLE PETRI
}

\begin{abstract}
Objective. A major cause of morbidity and mortality in systemic lupus erythematosus (SLE) is accelerated coronary atherosclerosis. New technology (computed tomographic angiography) can measure noncalcified coronary plaque (NCP), which is more prone to rupture. We report on a study of semiquantified NCP in SLE.

Methods. Patients with SLE $(\mathrm{n}=147)$ with no history of cardiovascular disease underwent 64-slice coronary multidetector computed tomography (MDCT). The MDCT scans were evaluated quantitatively by a radiologist, using dedicated software.

Results. The group of 147 patients with SLE was 86\% female, 70\% white, 29\% African American, and $3 \%$ other ethnicity. The mean age was 51 years. In our univariate analysis, the major traditional cardiovascular risk factors associated with noncalcified plaque were age $(\mathrm{p}=0.007)$, obesity $(\mathrm{p}=$ 0.03 ; measured as body mass index), homocysteine $(\mathrm{p}=0.05)$, and hypertension $(\mathrm{p}=0.04)$. Anticardiolipin ( $p=0.026$; but not lupus anticoagulant) and anti-dsDNA ( $p=0.03$ ) were associated with higher noncalcified plaque. Prednisone and hydroxychloroquine therapy had no effect, but methotrexate (MTX) use was associated with higher noncalcified plaque $(\mathrm{p}=0.0001)$. In the best multivariate model, age, current MTX use, and history of anti-dsDNA remained significant.

Conclusion. Our results suggest that serologic SLE (anti-dsDNA) and traditional cardiovascular risk factors contribute to semiquantified noncalcified plaque in SLE. The association with MTX is not understood, but should be replicated in larger studies and in multiple centers. (First Release Oct 1 2012; J Rheumatol 2012;39:2286-93; doi:10.3899/jrheum.120197)
\end{abstract}

\section{Key Indexing Terms: SYSTEMIC LUPUS ERYTHEMATOSUS RISK FACTORS}

Cardiovascular disease, specifically from accelerated premature atherosclerosis, is a major cause of morbidity and mortality in systemic lupus erythematosus (SLE) ${ }^{1}$. Patients with SLE are 2 to 9 times more likely than the general population to have myocardial infarctions ${ }^{2,3,4}$. The pathogenesis is multifactorial, including traditional cardiovascular risk factors, but also corticosteroids and inflammatory pathways $5,6,7,8$.

From the Division of Rheumatology, Department of Radiology, and Division of Cardiology, Johns Hopkins University School of Medicine; and the University of Maryland, Baltimore, Maryland, USA

The Hopkins Lupus Cohort is supported by a grant from the National Institutes of Health (NIH AR43727), and by grant UL1 RR025005 from the National Center for Research Resources, a component of the NIH, and the NIH Roadmap for Medical Research.

M. Petri, MD, MPH, Professor of Medicine; A.N. Kiani, MD, MPH, Division of Rheumatology, Johns Hopkins University School of Medicine; J. Vogel-Claussen, MD, Department of Radiology, Johns Hopkins University School of Medicine; A. Arbab-Zadeh, MD, PhD, Division of Cardiology, Johns Hopkins University School of Medicine; L.S. Magder, PhD, Professor of Epidemiology and Preventive Medicine, University of Maryland; J. Lima, MD, Division of Cardiology, Johns Hopkins University School of Medicine.

Address correspondence to Dr. M. Petri, Division of Rheumatology, Johns Hopkins University School of Medicine, 1830 East Monument Street, Suite 7500, Baltimore, MD 21205,USA.E-mail: mpetri@jhmi.edu

Accepted for publication August 20, 2012.

\section{CARDIOVASCULAR DISEASE COMORBIDITY}

Coronary calcium correlates well with the coronary atherosclerotic plaque burden. A report of the American College of Cardiology Foundation stated that helical computed tomography (CT) measurement of coronary artery calcium is recommended in patients with intermediate cardiovascular disease risk ${ }^{9}$. We have previously shown that age, body mass index (BMI), and diabetes mellitus are associated with coronary calcium in $\mathrm{SLE}^{10}$. Several other studies have shown more frequent and severe coronary artery calcification in SLE than in controls ${ }^{11,12}$.

The risk of an acute cardiac event is affected by the presence, extent, location, characteristics, and metabolic activity of coronary atherosclerotic plaque ${ }^{13,14,15}$. Noncalcified plaque may be more metabolically active than highly calcified plaque and preliminary data suggest that the presence of noncalcified or only partially calcified plaques is associated with greater risk of unstable presentation ${ }^{16}$. Motoyama, et al reported that the appearance of low attenuation plaque on multidetector CT was an independent predictor of acute coronary syndrome events for a 2-year followup period ${ }^{17}$. Noncalcified plaque may be present in the absence of coronary artery calcification: in a Japanese study, the prevalence of noncalcified plaque was $11.1 \%$ in patients with no coronary artery calcium and $23.4 \%$ in patients with mild coronary artery calcium ${ }^{18}$.

Personal non-commercial use only. The Journal of Rheumatology Copyright (C) 2012. All rights reserved. 
In our previous study of noncalcified plaque in SLE, we found that $54 \%$ of patients with SLE had noncalcified plaque $^{19}$. The aim of our current study was to quantify the burden of noncalcified plaque in SLE and to determine the association of semiquantified noncalcified coronary plaque (NCP) with clinical and laboratory manifestations of SLE.

\section{MATERIALS AND METHODS}

The patients were part of the Hopkins Lupus Cohort, a prospective longitudinal study of lupus activity and outcomes. Patients were invited to join the Hopkins Lupus Cohort if they had a clinical diagnosis of lupus. Consecutive cohort members who met inclusion/exclusion criteria were invited to participate in our substudy. Exclusion criteria included a serum creatinine level $\geq 1.2 \mathrm{mg} / \mathrm{dl}$, allergy to contrast material, pregnancy, or history of angina, myocardial infarction or stroke attributable to atherosclerotic disease. The study was approved by the Johns Hopkins University School of Medicine Institutional Review Board (NA_00002851). Written informed consent was obtained from each patient.

As part of the Hopkins Lupus Cohort Study, all patients had been seen quarterly since cohort entry for assessment of disease activity [by the Physician's Global Assessment, on a 0 -3 visual analog scale, and the Safety of Estrogens in Lupus Erythematosus National Assessment-Systemic Lupus Erythematosus Disease Activity Index (SELENA-SLEDAI) ${ }^{20}$. The patients also had regular laboratory tests (complete blood count, erythrocyte sedimentation rate, serum creatinine, cholesterol, urinalysis, urine protein/creatinine ratio, $\mathrm{C} 3, \mathrm{C} 4$, and anti-dsDNA), and cardiovascular risk factors were assessed.

Image acquisition and evaluation. Computed tomographic angiography (CTA) was performed to determine the prevalence and amount of noncalcified plaque. Multidetector CT (MDCT) scans were evaluated semiquantitatively by a blinded radiologist, using dedicated software (Circulation, Siemens Medical Solutions) ${ }^{21,22}$. The Agatston scoring system was used to quantify coronary artery calcification ${ }^{23}$. The standard coronary CT protocol was used with administration of intravenous Visipaque 320 at an injection rate of $5 \mathrm{cc} / \mathrm{s}$ for $100 \mathrm{cc}$ and an immediate $50 \mathrm{cc}$ saline chaser bolus at the same injection $\operatorname{sit}^{24}$. The presence or absence of calcification in each coronary artery was assessed (right coronary, circumflex, left main, and left anterior descending). Overall semiquantitative plaque score was the sum of plaque severity multiplied by plaque composition, divided by the number of vessels examined. Severity was calculated as $0=$ absent, $1=$ mild, $2=$ moderate, and $3=$ severe for each coronary artery segment, according to the American Heart Association classification ${ }^{25,26}$. Plaque composition was calculated as $0=0 \%, 1=1 \%-25 \%, 2=26 \%-50 \%, 3=51 \%-75 \%$, and $4=$ $76 \%-100 \%$ in the noncalcified portion of coronary plaque for each coronary artery segment (Figure 1). Mild stenosis was defined as $<25 \%$, moderate $25 \%-49 \%$, and severe $\geq 50 \%$. Coronary artery side branches were not included in the analysis for practical reasons, because the main branches have the bulk of disease. Similarly, noninterpretable coronary segments were excluded from our analysis. A segment was determined nonevaluable when either poor contrast-to-noise ratio or motion deemed detection of plaque impossible in the segment.

We tried to minimize partial volume by using thin- sliced pulse image processing, and we used specific construction kernels that decrease or minimize blooming of calcium. There might still be some residual effect. Kilovolt peak $(\mathrm{kVp})$ was adapted per the patient's BMI. For patients with a BMI > 30: $120 \mathrm{kVp}$; <30: $100 \mathrm{kVp}$; and < 20: $80 \mathrm{kVp}$.

Good to moderate interobserver agreement has been found in studies to detect noncalcified plaque ${ }^{27,28}$. To assess the degree of interobserver variability, we had a second physician read the scans for 9 patients ( 71 vessels). The correlation coefficient between the overall score between the 2 observers based on the 9 patients was 0.93 . The kappa statistic for the assessment of noncalcified plaque (present or absent) in the 71 vessels was 0.42 , which is considered moderate agreement.

Statistical analysis. All results for continuous variables were expressed as means, unless specified otherwise. Continuous variables were analyzed with a 2-sided t-test or ANOVA. Categorical variables were compared by Fisher's exact test. To the joint association between predictors and the quantity of noncalcified plaque, we fit multiple linear regression models. Statistical analysis was performed using SAS (v 9.2, SAS Institute).

\section{RESULTS}

One hundred forty-seven patients were enrolled. The mean age was 51 years (range 26-78 yrs). The group of patients was $86 \%$ female, $70 \%$ white, $27 \%$ African American, and $3 \%$ other ethnicity. The patients met these cumulative

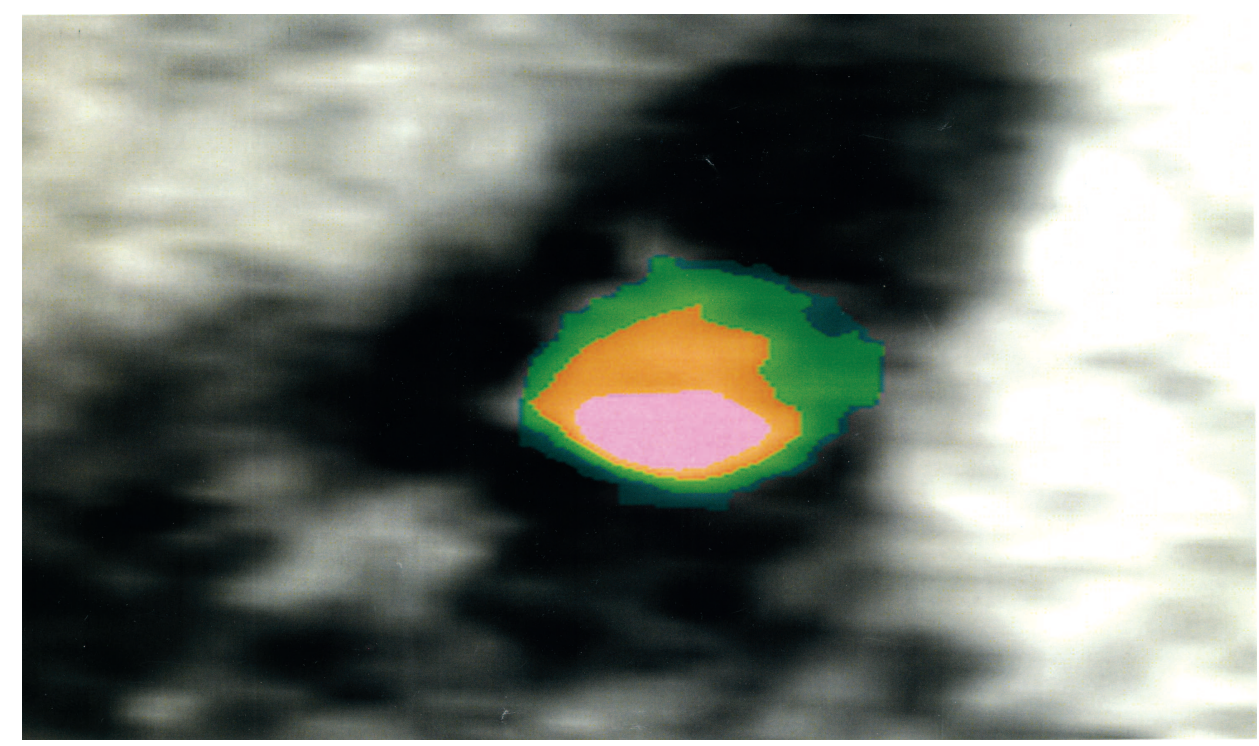

Figure 1. Cross section of the left anterior descending coronary artery, showing calcium (pink), vessel lumen (orange), and noncalcified plaque (green). 
American College of Rheumatology revised classification criteria for SLE ${ }^{29,30}$ : malar rash (56\%), discoid rash (20\%), photosensitivity (57\%), oral ulcers (56\%), arthritis (78\%), serositis $(49 \%)$, renal disorder (41\%), neurologic disorder (7\%), immunologic disorder (93\%), and antinuclear antibody positivity (97\%).

There was positive correlation between the Agatston score for coronary artery calcium and our semiquantified noncalcified plaque score $(r=0.29)$. This was mainly induced because almost all of those with a positive Agatston score had a positive noncalcified coronary plaque (NCP) score $(45 / 47,96 \%)$, while of those with an Agatston score of 0 , only half $(52 / 99,53 \%)$ had a positive NCP score.

Table 1 shows semiquantified NCP and its association with demographic variables, traditional cardiovascular risk factors, serologic variables, and treatment. Semiquantified noncalcified plaque was strongly associated with age $(\mathrm{p}=$ $0.007)$. There was an association with obesity $(\mathrm{p}=0.031)$ and with hypertension $(\mathrm{p}=0.041)$. Homocysteine had a borderline association (0.053).

Table 2 shows the association between semiquantified $\mathrm{NCP}$ and patient history of serologic results and past treatments. Only a history of anti-dsDNA was significantly associated with semiquantified noncalcified plaque $(\mathrm{p}=$ 0.03). Note, however, that based on the confidence interval, even in the absence of low $\mathrm{p}$ values, we cannot rule out the possibility of a moderate association between some of the predictors and mean NCP.

Table 3 shows the association of semiquantified NCP with serologies and treatments at the time of the NCP assessment. There was a strong association between semiquantified NCP and the current use of methotrexate

Table 1. Association of noncalcified coronary plaque with demographics and cardiovascular risk factors in our study group $(n=147)$. Data were missing for some variables.

\begin{tabular}{|c|c|c|c|c|}
\hline Characteristic & $\begin{array}{l}\text { Mean Noncalcified } \\
\text { Plaque Score (SD) }\end{array}$ & $\mathrm{p}$ & $\begin{array}{l}\text { Differences Between } \\
\text { Subgroups in Mean } \\
\text { Plaque Score Controlling } \\
\text { for Age }(95 \% \mathrm{CI})\end{array}$ & $\begin{array}{c}\mathrm{p} \\
\text { Controlling } \\
\text { for Age }\end{array}$ \\
\hline \multicolumn{5}{|l|}{ Age, yrs } \\
\hline$<45, \mathrm{n}=50$ & $0.14(0.20)$ & \multirow[t]{3}{*}{0.007} & Reference group & \\
\hline $45-55, \mathrm{n}=53$ & $0.22(0.31)$ & & $0.09(-0.02,0.20)$ & \\
\hline $55+, \mathrm{n}=42$ & $0.36(0.33)$ & & $0.23(0.11,0.34)$ & \\
\hline \multicolumn{5}{|l|}{ Ethnicity } \\
\hline White, $\mathrm{n}=102$ & $0.24(0.32)$ & \multirow[t]{3}{*}{0.96} & Reference group & \multirow[t]{3}{*}{0.99} \\
\hline Black, $\mathrm{n}=39$ & $0.23(0.23)$ & & $-0.00(-0.11,0.10)$ & \\
\hline Other, $\mathrm{n}=6$ & $0.21(0.23)$ & & $0.02(-0.24,0.27)$ & \\
\hline \multicolumn{5}{|l|}{ Sex } \\
\hline Female, $\mathrm{n}=126$ & $0.22(0.26)$ & \multirow[t]{2}{*}{0.11} & Reference group & \multirow[t]{2}{*}{0.14} \\
\hline Male, $\mathrm{n}=20$ & $0.33(0.43)$ & & $0.10(-0.03,0.23)$ & \\
\hline \multicolumn{5}{|l|}{ Smoking history } \\
\hline No, $n=95$ & $0.22(0.30)$ & \multirow[b]{2}{*}{0.42} & Reference group & \multirow[b]{2}{*}{0.75} \\
\hline Yes, $\mathrm{n}=51$ & $0.26(0.27)$ & & $0.02(-0.08,0.11)$ & \\
\hline \multicolumn{5}{|c|}{ Menopause (women only) } \\
\hline No, $n=52$ & $0.17(0.22)$ & \multirow[t]{2}{*}{0.060} & Reference group & \multirow[t]{2}{*}{0.19} \\
\hline Yes, $\mathrm{n}=70$ & $0.26(0.29)$ & & $-0.08(-0.04,0.20)$ & \\
\hline \multicolumn{5}{|l|}{ Body mass index } \\
\hline$<25, \mathrm{n}=34$ & $0.14(0.23)$ & \multirow{3}{*}{$0.016^{*}$} & Reference group & \multirow{3}{*}{$0.031 * *$} \\
\hline $25-29, \mathrm{n}=36$ & $0.26(0.34)$ & & $0.11(-0.01,0.22)$ & \\
\hline $30+, \mathrm{n}=34$ & $0.31(0.29)$ & & $0.14(0.03,0.25)$ & \\
\hline \multicolumn{5}{|c|}{ History of hypertension } \\
\hline No, $n=47$ & $0.13(0.18)$ & \multirow[t]{2}{*}{0.0044} & Reference group & \multirow[t]{2}{*}{0.041} \\
\hline Yes, $\mathrm{n}=99$ & $0.28(0.32)$ & & $0.10(-0.20,-0.00)$ & \\
\hline \multicolumn{5}{|l|}{ Homocysteine } \\
\hline Low, $\mathrm{n}=66$ & $0.19(0.22)$ & \multirow[t]{2}{*}{0.022} & Reference group & \multirow[t]{2}{*}{0.053} \\
\hline High, $\mathrm{n}=64$ & $0.31(0.35)$ & & $0.10(-0.00,0.20)$ & \\
\hline \multicolumn{5}{|l|}{ History of diabetes } \\
\hline No, $\mathrm{n}=137$ & $0.24(0.29)$ & \multirow[t]{2}{*}{0.44} & Reference group & \multirow[t]{2}{*}{0.63} \\
\hline Yes, $\mathrm{n}=9$ & $0.16(0.26)$ & & $-0.05(-0.23,0.14)$ & \\
\hline \multicolumn{5}{|c|}{ History of high cholesterol } \\
\hline No, $n=53$ & $0.15(0.20)$ & \multirow[t]{2}{*}{0.0075} & Reference group & \multirow[t]{2}{*}{0.18} \\
\hline Yes, $\mathrm{n}=93$ & $0.28(0.33)$ & & $0.07(-0.03,0.17)$ & \\
\hline
\end{tabular}

$* \mathrm{p}=0.016$ for trend with body mass index as a continuous predictor. $* * \mathrm{p}=0.031$ for trend with body mass index as a continuous predictor, controlling for age. 
Table 2. Association of noncalcified coronary plaque with history of serologic findings and treatment history in our study group $(\mathrm{n}=147)$. Data were missing for some variables.

\begin{tabular}{|c|c|c|c|c|}
\hline Factor & $\begin{array}{l}\text { Mean Noncalcified } \\
\text { Plaque Score (SD) }\end{array}$ & $\mathrm{p}$ & $\begin{array}{l}\text { Differences Between } \\
\text { Subgroups in Mean } \\
\text { Plaque Score Controlling } \\
\text { for Age }(95 \% \mathrm{CI})\end{array}$ & $\begin{array}{c}\mathrm{p} \\
\text { Controlling } \\
\text { for Age }\end{array}$ \\
\hline \multicolumn{5}{|c|}{ Lupus nephritis (biopsy confirmed) } \\
\hline No, $n=115$ & $0.24(0.31)$ & \multirow[t]{2}{*}{0.41} & Reference group & \multirow[t]{2}{*}{0.76} \\
\hline Yes, $\mathrm{n}=32$ & $0.20(0.23)$ & & $0.02(-0.09,0.13)$ & \\
\hline \multicolumn{5}{|l|}{ Anti-dsDNA } \\
\hline No, $n=46$ & $0.20(0.22)$ & \multirow[t]{2}{*}{0.32} & Reference group & \multirow[t]{2}{*}{0.030} \\
\hline Yes, $\mathrm{n}=100$ & $0.25(0.32)$ & & $0.11(0.01,0.21)$ & \\
\hline \multicolumn{5}{|c|}{ Anticardiolipin antibody } \\
\hline No, $\mathrm{n}=50$ & $0.18(0.27)$ & \multirow[b]{2}{*}{0.11} & Reference group & \multirow[b]{2}{*}{0.26} \\
\hline Yes, $\mathrm{n}=96$ & $0.26(0.30)$ & & $0.06(-0.04,0.15)$ & \\
\hline \multicolumn{5}{|c|}{ Lupus anticoagulant } \\
\hline No, $n=89$ & $0.20(0.26)$ & \multirow[t]{2}{*}{0.090} & Reference group & \multirow[t]{2}{*}{0.12} \\
\hline Yes, $\mathrm{n}=57$ & $0.28(0.34)$ & & $0.07(-0.02,0.16)$ & \\
\hline \multicolumn{5}{|l|}{ Corticosteroids } \\
\hline No, $n=23$ & $0.26(0.36)$ & \multirow[b]{2}{*}{0.66} & Reference group & \multirow[b]{2}{*}{0.99} \\
\hline Yes, $\mathrm{n}=123$ & $0.23(0.28)$ & & $-0.00(-0.12,0.12)$ & \\
\hline \multicolumn{5}{|c|}{ Hydroxychloroquine } \\
\hline No, $n=4$ & $0.28(0.31)$ & \multirow[b]{2}{*}{0.76} & Reference group & \multirow[b]{2}{*}{0.58} \\
\hline Yes, $\mathrm{n}=142$ & $0.23(0.29)$ & & $-0.08(-0.20,0.35)$ & \\
\hline \multicolumn{5}{|l|}{ Azathioprine } \\
\hline No, $n=108$ & $0.25(0.31)$ & \multirow[b]{2}{*}{0.36} & Reference group & \multirow[b]{2}{*}{0.72} \\
\hline Yes, $\mathrm{n}=37$ & $0.18(0.23)$ & & $-0.02(-0.12,0.08)$ & \\
\hline \multicolumn{5}{|l|}{ Cytoxan } \\
\hline No, $n=115$ & $0.24(0.31)$ & \multirow[b]{2}{*}{0.33} & Reference group & \multirow[b]{2}{*}{0.59} \\
\hline Yes, $\mathrm{n}=30$ & $0.19(0.22)$ & & $-0.03(-0.14,0.08)$ & \\
\hline \multicolumn{5}{|l|}{ Methotrexate } \\
\hline No, $\mathrm{n}=121$ & $0.22(0.27)$ & 0.18 & Reference group & 0.12 \\
\hline Yes, $\mathrm{n}=24$ & $0.31(0.40)$ & & $0.10(-0.02,0.22)$ & \\
\hline NSAID & & & & \\
\hline No, $n=27$ & $0.19(0.19)$ & 0.38 & Reference group & 0.57 \\
\hline Yes, $\mathrm{n}=119$ & $0.25(0.24)$ & & $0.03(-0.08,0.15)$ & \\
\hline Anti-Ro & & & & \\
\hline No, $\mathrm{n}=87$ & $0.25(0.31)$ & 0.084 & Reference group & 0.20 \\
\hline Yes, $\mathrm{n}=19$ & $0.15(0.19)$ & & $-0.07(-0.18,0.04)$ & \\
\hline Anti-Sm & & & & \\
\hline No, $n=122$ & $0.24(0.30)$ & 0.38 & Reference group & 0.96 \\
\hline Yes, $\mathrm{n}=24$ & $0.18(0.23)$ & & $0.00(-0.12,0.13)$ & \\
\hline Anti-RNP & & & & \\
\hline No, $\mathrm{n}=115$ & $0.24(0.30)$ & & Reference group & \\
\hline Yes, $\mathrm{n}=31$ & $0.19(0.25)$ & 0.35 & $-0.02(-0.13,0.86)$ & 0.70 \\
\hline Anti-La & & & & \\
\hline No, $\mathrm{n}=131$ & $0.24(0.30)$ & 0.29 & Reference group & 0.39 \\
\hline Yes, $\mathrm{n}=15$ & $0.16(0.17)$ & & $-0.07(-0.22,0.87)$ & \\
\hline
\end{tabular}

NSAID: nonsteroidal antiinflammatory drugs.

(MTX; $\mathrm{p}=0.0001)$, but not with other treatments [including prednisone, hydroxychloroquine, azathioprine, mycophenolate mofetil, or nonsteroidal antiinflammatory drugs (NSAID)]. There was also an association between current anticardiolipin antibodies (aCL) immunoglobulin G > $20 \mathrm{IU}$ and semiquantified NCP ( $\mathrm{p}=0.026)$. Complement levels (C3, C4) and lupus anticoagulant (by dilute Russell's viper venom time) were not associated.

In the multivariate analysis (Table 4), semiquantified
NCP was associated with age $(p=0.0001)$, current MTX use $(\mathrm{p}=0.0005)$, BMI $(\mathrm{p}=0.058)$, and anti-dsDNA history $(\mathrm{p}=$ 0.019 ). Hypertension, aCL, and homocysteine were no longer significant in the multivariate analysis.

\section{DISCUSSION}

To our knowledge, ours is the first study of semiquantified NCP in SLE. In our previous analysis of presence or absence of noncalcified plaque in SLE, we found that noncalcified 
Table 3. Association of noncalcified coronary plaque with serologic findings and treatment from the same day (current) visit in our study group $(n=147)$. Data were missing for some variables.

\begin{tabular}{|c|c|c|c|c|}
\hline Factor & $\begin{array}{l}\text { Mean Noncalcified } \\
\text { Plaque Score (SD) }\end{array}$ & $\mathrm{p}$ & $\begin{array}{c}\text { Differences Between } \\
\text { Subgroups in Mean } \\
\text { Plaque Score Controlling } \\
\text { for Age }(95 \% \mathrm{CI})\end{array}$ & $\begin{array}{l}\mathrm{p} \\
\text { Controlling } \\
\text { for Age }\end{array}$ \\
\hline \multicolumn{5}{|l|}{$\mathrm{C} 3<79 \mathrm{mg} / \mathrm{dl}$} \\
\hline No, $n=114$ & $0.23(0.30)$ & \multirow[t]{2}{*}{0.90} & Reference group & \multirow[t]{2}{*}{0.53} \\
\hline Yes, $\mathrm{n}=25$ & $0.22(0.27)$ & & $0.04(-0.08,0.16)$ & \\
\hline \multicolumn{5}{|l|}{$\mathrm{C} 4<2 \mathrm{mg} / \mathrm{dl}$} \\
\hline No, $n=119$ & $0.24(0.30)$ & \multirow[t]{2}{*}{0.85} & Reference group & \multirow[t]{2}{*}{0.32} \\
\hline Yes, $\mathrm{n}=20$ & $0.23(0.29)$ & & $0.07(-0.07,0.20)$ & \\
\hline \multicolumn{5}{|c|}{ Lupus anticoagulant (dRVVT) } \\
\hline No, $\mathrm{n}=107$ & $0.23(0.30)$ & \multirow[t]{2}{*}{0.59} & Reference group & \multirow[t]{2}{*}{0.62} \\
\hline Yes, $\mathrm{n}=23$ & $0.26(0.30)$ & & $0.03(-0.10,0.16)$ & \\
\hline \multicolumn{5}{|c|}{ Anticardiolipin IgG $>20$} \\
\hline No, $n=126$ & $0.22(0.29)$ & \multirow[b]{2}{*}{0.046} & Reference group & \multirow[b]{2}{*}{0.026} \\
\hline Yes, $\mathrm{n}=9$ & $0.42(0.37)$ & & $0.22(0.03,0.41)$ & \\
\hline \multicolumn{5}{|c|}{ Current anti-dsDNA } \\
\hline No, $n=109$ & 0.25 & \multirow[t]{2}{*}{0.20} & Reference group & \multirow[t]{2}{*}{0.80} \\
\hline Yes, $\mathrm{n}=27$ & 0.17 & & $-0.02(-0.14,0.11)$ & \\
\hline \multicolumn{5}{|l|}{ Corticosteroids } \\
\hline No, $\mathrm{n}=98$ & $0.25(0.30)$ & \multirow[t]{2}{*}{0.29} & Reference group & \multirow[t]{2}{*}{0.66} \\
\hline Yes, $\mathrm{n}=48$ & $0.20(0.27)$ & & $-0.02(-0.12,0.08)$ & \\
\hline \multicolumn{5}{|c|}{ Hydroxychloroquine } \\
\hline No, $n=24$ & $0.22(0.23)$ & \multirow[t]{2}{*}{0.79} & Reference group & \multirow[t]{2}{*}{0.99} \\
\hline Yes, $\mathrm{n}=122$ & $0.24(0.30)$ & & $0.00(-0.12,0.12)$ & \\
\hline \multicolumn{5}{|l|}{ Azathioprine } \\
\hline No, $n=134$ & $0.24(0.30)$ & \multirow[t]{2}{*}{0.53} & Reference group & \multirow[t]{2}{*}{0.61} \\
\hline Yes, $n=13$ & $0.18(0.19)$ & & $-0.04(-0.20,0.12)$ & \\
\hline \multicolumn{5}{|l|}{ Methotrexate } \\
\hline No, $n=138$ & $0.21(0.26)$ & \multirow[t]{2}{*}{0.0001} & Reference group & 0.0001 \\
\hline Yes, $\mathrm{n}=9$ & $0.59(0.50)$ & & $0.38(0.19,0.56)$ & \\
\hline Mycophenolate & & & & \\
\hline No, $\mathrm{n}=128$ & 0.25 & 0.097 & Reference group & 0.52 \\
\hline Yes, $\mathrm{n}=19$ & 0.13 & & $-0.04(-0.18,0.09)$ & \\
\hline NSAID & & & & \\
\hline No, $n=91$ & 0.25 & 0.45 & Reference group & 0.37 \\
\hline Yes, $\mathrm{n}=55$ & 0.21 & & $-0.04(-0.13,0.05)$ & \\
\hline Physical global & & & & \\
\hline$<0.5$ & 0.19 & 0.37 & Reference group & 0.27 \\
\hline $0.5-0.99$ & 0.27 & & $0.08(-0.02,0.19)$ & \\
\hline $1+$ & 0.24 & & $0.07(-0.06,0.19)$ & \\
\hline Current SLED & & & & \\
\hline $0-2$ & 0.23 & 0.71 & Reference group & 0.34 \\
\hline $3+$ & 0.25 & & $0.05(-0.05,-0.15)$ & \\
\hline
\end{tabular}

dRVVT: dilute Russell's viper venom test; NSAID: nonsteroidal antiinflammatory drugs; SLEDAI: Systemic Lupus Erythematosus Disease Activity Index.

plaque was present more often in those with higher disease activity, current immunosuppressive use, and current NSAID use ${ }^{10}$. Our current study enrolled a larger number of patients and used new technology to quantify the burden of noncalcified plaque.

We found that $53 \%$ of patients with SLE who had no coronary calcification had noncalcified plaque. Hausleiter, et al found noncalcified plaque in only $16 \%$ of patients with a coronary artery calcium score of 0 , Cheng, et al $6.5 \%$, Sosnowski, et al 12\%, and Rubinshtein, et al 7\% $31,32,33,34$.
We believe that the higher prevalence in SLE represents the increased inflammatory burden of SLE.

Obesity has been shown to be associated with noncalcified plaque in the general population ${ }^{35}$. In one study, those with higher BMI were 2.76 times more likely to have noncalcified plaque compared with those with a normal $\mathrm{BMI}^{36}$. We have previously shown higher BMI to be associated with coronary artery calcium, as well ${ }^{10}$. Rupture of vulnerable plaque may be associated with metabolic syndrome, especially in the setting of abdominal obesity ${ }^{37}$. 
Table 4. Multivariable model to predict mean semiquantified noncalcified coronary plaque.

\begin{tabular}{lcc}
\hline Variable & $\begin{array}{c}\text { Effect on Mean } \\
\text { Noncalcified Plaque } \\
\text { Score }(95 \% \mathrm{CI})\end{array}$ & \\
\hline Age (per 10 yrs) & $0.08(0.04,0.12)$ & $<0.0001$ \\
Body mass index (per unit change) & $0.03(0.00,0.07)$ & 0.058 \\
Hypertension & $0.08(-0.02,0.17)$ & 0.11 \\
Anti-dsDNA history & $0.10(0.01,0.20)$ & 0.032 \\
Male gender & $0.11(-0.01,0.23)$ & 0.067 \\
Current methotrexate use & $0.34(0.15,0.53)$ & 0.0005 \\
\hline
\end{tabular}

However, the association of obesity with semiquantified noncalcified plaque was only borderline in the multivariate model.

Our quantitative analysis of noncalcified plaque failed to show an association with measures of SLE disease activity, contrary to our previous qualitative analysis ${ }^{19}$. In our quantitative analysis, noncalcified plaque was not associated with either the physician global assessment or SELENA-SLEDAI. Several other studies have failed to show an association of SLE disease activity with subclinical measures of atherosclerosis $38,39,40$. A recent study of 139 patients with SLE found that a longer period with moderate to severe activity (as measured by SLEDAI) was associated with coronary artery calcium ${ }^{41}$. A Canadian study also found that disease activity as measured by SLEDAI was associated with risk for coronary artery disease ${ }^{42}$. Finally, our own longitudinal study did find that disease activity, measured by SELENA-SLEDAI, increased the risk of cardiovascular events ${ }^{4}$.

It is surprising that $\mathrm{aCL}$, rather than the lupus anticoagulant, was the significant antiphospholipid antibody (aPL) in our models. The lupus anticoagulant has been a more specific predictor of thrombosis in multiple studies, including our own ${ }^{43}$. However, aCL $\mathrm{a}^{44}$ and other $\mathrm{aPL}^{45}$, including low-density lipoprotein ${ }^{46}$, have been associated with atherosclerotic cardiovascular disease in some studies. In our previous study of coronary artery calcium, however, $\mathrm{aCL}$ was not associated with atherosclerotic cardiovascular disease $^{10}$.

The finding of the association of noncalcified plaque with current MTX treatment is based on 9 SLE patients with noncalcified plaque who were taking MTX. In our study, the weekly MTX dosage ranged from 15 to $25 \mathrm{mg}$. At the time of the scan, the patients taking MTX had mild to moderate arthritis activity. In our study, 9 patients who were taking MTX did not differ from the other patients in their homocysteine levels. There are several studies in rheumatoid arthritis (RA) showing that MTX use is associated with a reduced risk of cardiovascular events ${ }^{47,48,49,50}$. In a study of 1240 patients with RA, deaths due to cardiovascular disease were reduced $70 \%$ by $\mathrm{MTX}^{47}$. Another large multinational study of 4363 patients with RA showed an $18 \%$ reduction in the risk of myocardial infarction in those treated with MTX for 1 year $^{48}$. In a small study of 39 patients with RA, treatment with MTX decreased carotid intima-media thickness by $17.6 \%{ }^{51}$. Our finding is counterintuitive, because MTX has antiinflammatory effects due to its capacity to release adenosine. This increases the expression of enzymes involved in metabolizing cholesterol and of transporters involved in the reverse transport of cholesterol ${ }^{52}$.

In our analysis, semiquantified noncalcified plaque was associated with homocysteine in univariate but not multivariate analysis. We have previously shown homocysteine to be a risk factor for atherosclerotic events and stroke in $\mathrm{SLE}^{53}$. Elevated levels of homocysteine are common in SLE $^{54,55}$. The role of homocysteine as a determinant of atherosclerotic events has been controversial ${ }^{56,57,58}$.

Our study has several limitations. When we did not find statistically significant relationships, we could not rule out moderate associations, as demonstrated by the size of the confidence intervals. These show the range of associations consistent with our data and indicate that in many cases, even though we did not detect significance, we cannot rule out clinically relevant associations. Analysis of outcomes (death from cardiac causes, cardiac arrest, myocardial infarction, or rehospitalization because of unstable or progressive angina) was not possible, given the short followup after CTA. Our study population was also limited to SLE patients with no chronic kidney disease.

Our study of semiquantified noncalcified plaque in SLE found that NCP is common in SLE, increases with age, and contributes to the overall atherosclerotic burden. Age, obesity, homocysteine, and possibly hypertension and SLE-specific factors (aCL, history of anti-dsDNA) are associated with the extent of noncalcified plaque at the univariate or multivariate level. The association with current MTX therapy is unexplained and of concern. The quantification of NCP is a major research advance, but its value for clinical management has not been established at present.

\section{REFERENCES}

1. Urowitz MB, Bookman AAM, Koehler BE, Gordon DA, Smythe HA, Ogryzlo MA. The bimodal mortality pattern of systemic lupus erythematosus. Am J Med 1976;60:221-5.

2. Manzi S, Meilahn EN, Rairie JE. Age-specific incidence rates of myocardial infarction and angina in women with systemic lupus erythematosus: Comparison with the Framingham Study. Am J Epidemiol 1997;145:408-15.

3. Jonsson H, Nived O, Sturfelt G. Outcome in systemic lupus erythematosus: A prospective study of patients from a defined population. Medicine 1989;68:141-50.

4. Magder LS, Petri M. Incidence and risk factors for adverse cardiovascular events among patients with systemic lupus erythematosus. Am J Epidemiol 2012 (in press).

5. Westerweel PE, Luyten RK, Koomans HA, Derksen RH, Verhaar MC. Premature atherosclerotic cardiovascular disease in systemic lupus erythematosus. Arthritis Rheum 2007;56:1384-96.

6. Reiss AB. Effects of inflammation on cholesterol metabolism: impact on systemic lupus erythematosus. Curr Rheumatol Rep

Personal non-commercial use only. The Journal of Rheumatology Copyright @ 2012 . All rights reserved. 
2009;11:255-60.

7. Frieri M. Accelerated atherosclerosis in systemic lupus erythematosus: Role of proinflammatory cytokines and therapeutic approaches. Curr Allergy Asthma Rep 2012;12:25-32 .

8. Bruce IN. "Not only ... but also": Factors that contribute to accelerated atherosclerosis and premature heart disease in systemic lupus atherosclerosis. Rheumatology 2005;44:1492-502.

9. Greenland P. ACCF/AHA 2007 Clinical expert consensus document on coronary artery calcium scoring by computed tomography in global risk assessment and in evaluation of patients with chest pain. Circulation 2007;115:402-26.

10. Kiani AN, Magder L, Petri M. Coronary calcium in SLE is associated with traditional cardiovascular risk factors, but not with disease activity. J Rheumatol 2008;35:1300-6.

11. Asanuma Y, Oeser A, Shintani AK, Turner E, Olsen N, Fazio S. Premature coronary-artery atherosclerosis in systemic lupus erythematosus. N Engl J Med 2003;349:2407-15.

12. Asanuma Y, Chung CP, Oeser A, Shintani AK, Stanley E, Raggi P. Increased concentration of proatherogenic inflammatory cytokines in systemic lupus erythematosus: Relationship to cardiovascular risk factors. J Rheumatol 2006;33:539-45.

13. Fuster V, Fayad ZA, Badimon JJ. Acute coronary syndromes: biology. Lancet 1999;353:5-9.

14. Falk E, Shah PK, Fuster V. Coronary plaque disruption. Circulation 1995;92:657-71.

15. Arbab-Zadeh A, Nakano M, Virmani R, Fuster V. Acute coronary events. Circulation 2012;125:1147-56.

16. Motoyama S, Kondo T, Sarai M, Sugiura A, Harigaya H, Sato T, et al. Multislice computed tomographic characteristics of coronary lesions in acute coronary syndromes. J Am Coll Cardiol 2007;50:319-26.

17. Motoyama S, Sarai M, Harigaya H, Anno H, Inoue K, Hara T, et al. Computed tomographic angiography characteristics of atherosclerotic plaques subsequently resulting in acute coronary syndrome. J Am Coll Cardiol 2009;54:49-57.

18. Iwasaki K, Matsumoto T, Aono H, Furukawa H, Samukawa M. Prevalence of noncalcified coronary plaque on 64 slice computed tomography in asymptomatic patients with zero and low coronary artery calcium. Can J Cardiol 2010;26:377-80.

19. Kiani AN, Vogel-Claussen J, Magder LS, Petri M. Noncalcified coronary plaque in systemic lupus erythematosus. J Rheumatol 2010;37:579-84.

20. Petri M, Kim MY, Kalunian KC, Grossman J, Hahn BH, Sammaritano LR, et al: OC-SELENA Trial. Combined oral contraceptives in women with systemic lupus erythematosus. N Engl J Med 2005;353:2550-8.

21. Leontiev O, Dubinsky TJ. CT-based calcium scoring to screen for coronary artery disease: Why aren't we there yet? AJR Am J Roentgenol 2007;189:1061-3.

22. Mahnken AH, Wildberger JE, Koos R, Gunther RW. Multislice spiral computed tomography of the heart: Technique, current applications and perspective. Cardiovasc Intervent Radiol 2005:28:388-99.

23. Budoff MJ, Georgiou D, Brody A, Agatston AS, Kennedy J, Wolfkiel C. Ultrafast computed tomography as a diagnostic modality in the detection of coronary artery disease: A multicenter disease: a multicenter study. Circulation 1996:93:898-904.

24. Vogel-Claussen J, Fishman EK, Bluemke DA. Novel cardiovascular MRI and CT methods for evaluation of ischemic heart disease. Expert Rev Cardiovasc Ther 2007;5:791-802.

25. Feuchtner GM, Cury RC, Jodocy D, Friedrich GJ, Blumenthal RS, Budoff MJ, et al. Differences in coronary plaque composition by noninvasive computed tomography angiography in individuals with and without obstructive coronary artery disease. Atherosclerosis 2011;215:90-5.
26. Austen WG, Edwards JE, Frye RL. A reporting system on patients evaluated for coronary artery disease: Report of the Ad Hoc Committee for Grading of Coronary Artery Disease, Council On Cardiovascular Surgery, American Heart Association. Circulation 1975;51:5-40.

27. Leber AW, Knez A, White CW. Composition of coronary atherosclerotic plaques in patients with acute myocardial infarction and stable angina pectoris determined by contrast-enhanced multislice computed tomography. Am J Cardiol 2003;91:714-8.

28. Ferencik M, Nieman K, Achenbach S. Noncalcified and calcified coronary plaque detection by contrast-enhanced multi-detector computed tomography: A study of interobserver agreement. J Am Coll Cardiol 2006;47:207-9.

29. Tan EM, Cohen AS, Fries JF. The 1982 revised criteria for the classification of systemic lupus erythematosus. Arthritis Rheum 1982;25:1271-7.

30. Perez-Gutthann S, Petri M, Hochberg MC. Comparison of different methods of classifying patients with systemic lupus erythematosus. J Rheumatol 1991;18:116-9.

31. Hausleiter J, Meyer T, Hadamitzky, Kastrati A, Martinoff S, Schomig A. Prevalence of noncalcified coronary plaques by 64-slice computed tomography in patients with an intermediate risk for significant coronary artery disease. J Am Coll Cardiol 2006;48:312-8.

32. Cheng VY, Lepor NE, Madyoon H, Eshaghian S, Naraqhi AL, Shah $\mathrm{PK}$. Presence and severity of noncalcified plaque on 64-slice computed tomographic coronary angiography in patients with zero and low coronary artery calcium. Am J Cardiol 2007;99:1183-6.

33. Sosnowski M, Pysz P, Szymanski L, Gola A, Tendera M. Negative calcium score and the presence of obstructive coronary lesions in patients with intermediate CAD probability. Int J Cardiol 2011;148:e16-8.

34. Rubinshtein R, Gaspar T, Halon DA, Goldstein J, Peled N, Lewis BS. Prevalence and extent of obstructive coronary artery disease in patients with zero or low calcium score undergoing 64-slice cardiac multidetector computed tomography for evaluation of a chest pain syndrome. Am J Cardiol 2007;99:472-5.

35. Aggarwal NR, Knickelbine T, Tande A, Stoltzfus L, Lesser JR, Schwartz RS. Noncalcified plaque: relationship between results of multislice computed tomography, risk factors, and late clinical outcome. Catheter Cardiovasc Interv 2011;78:1116-24.

36. Ismaeel H, Tellalian D, Hamirani YS, Kadakia J, Nasir K, Budoff MJ. Effect of obesity on coronary artery plaque using 64 slice multidetector cardiac computed tomography angiography. Int $\mathrm{J}$ Cardiol 2008;30:358-60.

37. Kato M, Dote K, Naganuma T, Sasaki S, Ueda K, Okita M, et al. Clinical predictors of culprit plaque rupture assessed on intravascular ultrasound in acute coronary syndrome. Circ J 2010;74:1936-42.

38. Manger K, Kusus M, Forster C. Factors associated with coronary artery calcification in young female patients with systemic lupus erythematosus. Ann Rheum Dis 2003;62:846-50.

39. Rho YH, Chung CP, Oeser A. Novel cardiovascular risk factors in premature coronary atherosclerosis associated with systemic lupus erythematosus. J Rheumatol 2008;35:1789-94.

40. Ahmad Y, Shelmerdine J, Bodill H. Subclinical atherosclerosis in systemic lupus erythematosus (SLE): The relative contribution of classic risk factors and lupus phenotype. Rheumatology 2007;46:983-8.

41. Romero-Diaz J, Vargas-Vorackova V, Kimura-Hayama E, Sanchez-Guerrero J. Systemic lupus erythematosus risk factors for coronary artery calcifications. Rheumatology 2012;51:110-9.

42. Hochman J, Urowitz MB, Ibanez D, Gladman DD. Hormone replacement therapy in systemic lupus erythematosus. Lupus 2009;18:313-7. 
43. Petri M, Rheinschimdt M, Hellmann D, Corash L. The frequency of lupus anticoagulant in systemic lupus erythematosus. A study of sixty consecutive patients by activated partial thromboplastin time, Russell viper venom time, and anticardiolipin antibody level. Ann Intern Med 1987;106:524-31.

44. Glueck CJ, Lang JE, Tracy T, Wang P. Evidence that anticardiolipin antibodies are independent risk factors for atherosclerotic vascular disease. Am J Cardiol 1999;83:1490-4.

45. Farzaneh-Far A, Roman MJ, Lockshin MD, Paget SA, Crow MK, Salmon JE. Relationship of antiphospholipid antibodies to cardiovascular manifestations of systemic lupus erythematosus. Arthritis Rheum 2006;54:3918-25.

46. Sherer Y, Zinger H, Shoenfeld Y. Atherosclerosis in systemic lupus erythematosus. Autoimmunity 2010;43:98-102.

47. Choi HK, Hernan MA, Seeger JD, Robins JM, Wolfe F. Methotrexate and mortality in patients with rheumatoid arthritis: A prospective study. Lancet 2002;359:1173-7.

48. Naranjo A, Sokka T, Descalzo MA, Calvo-Alén J, Hørslev-Petersen $\mathrm{K}$, Luukkainen RK, et al. Cardiovascular disease in patients with rheumatoid arthritis: Results from QUEST-RA study. Arthritis Res Ther 2008;10:R30.

49. Prodanovich S, Ma F, Taylor JR, Pezon C, Fasihi T, Kirsner RS. Methotrexate reduces incidence of vascular diseases in veterans with psoriasis or rheumatoid arthritis. J Am Acad Dermatol 2005;52:262-7.

50. van Halm V, Nurmohamed MT, Twisk JW, Dijkmans BA, Voskuyl AE. Disease-modifying antirheumatic drugs are associated with a reduced risk for cardiovascular disease in patients with rheumatoid arthritis: A case control study. Arthritis Res Ther 2006;8:R151.
51. Wallberg-Jonsson S, Ohman M, Rantapaa-Dahlqvist S. Which factors are related to the presence of atherosclerosis in rheumatoid arthritis? Scand J Rheumatol 2004;33:373-9.

52. Reiss AB, Carsons SE, Anwar K, Rao S, Edelman SD, Zhang H, et al. Atheroprotective effects of methotrexate on reverse cholesterol transport proteins and foam cell transformation in human THP-1 monocyte/macrophages. Arthritis Rheum 2008;58:3675-83.

53. Petri M, Roubenoff R, Dallal GE, Nadeau MR, Rosenberg IH. Plasma homocysteine as a risk factor for atherothrombotic events in systemic lupus erythematosus. Lancet 1996;348:1120-4.

54. Fijnheer R, Roest M, Haas FJ, De Groot PG, Derksen RH. Homocysteine, methylene tetrahydrofolate reductase polymorphism, antiphospholipid antibodies, and thromboembolic events in SLE: A retrospective cohort study. J Rheumatol 1998;25:1737-42.

55. Refai TM, Al-Salem IH, Nkansa-Dwamena D, Al-Salem MH. Hyperhomocysteinaemia and risk of thrombosis in systemic lupus erythematosus patients. Clin Rheumatol 2002;21:457-61.

56. Lonn E, Yusuf S, Arnold MJ, Held C. Homocysteine lowering with folic acid and B vitamins in vascular disease. N Engl J Med 2006;354:1567-77.

57. Bonaa KH, Ueland PM, Schirmer H, Wang H, Arnesen E. Homocysteine lowering and cardiovascular events after acute myocardial infarction. N Engl J Med 2006;354:1578-88.

58. Wang X, Qin X, Demirtas H, Li J, Mao G, Huo Y, et al. Efficacy of folic acid supplementation in stroke prevention: A meta-analysis. Lancet 2007;369:1876-82. 


\section{Correction}

Semiquantified Noncalcified Coronary Plaque in Systemic Lupus Erythematosus

Kiani AN, Vogel-Claussen J, Zadeh A, Magder LS, Lima J, Petri M. Semiquantified noncalcified coronary plaque in systemic lupus erythematosus. J Rheumatol 2012;39:XXX. The name of the third author should be Armin Arbab-Zadeh. We regret the error.

doi:10.3899/jrheum.120197.C1 